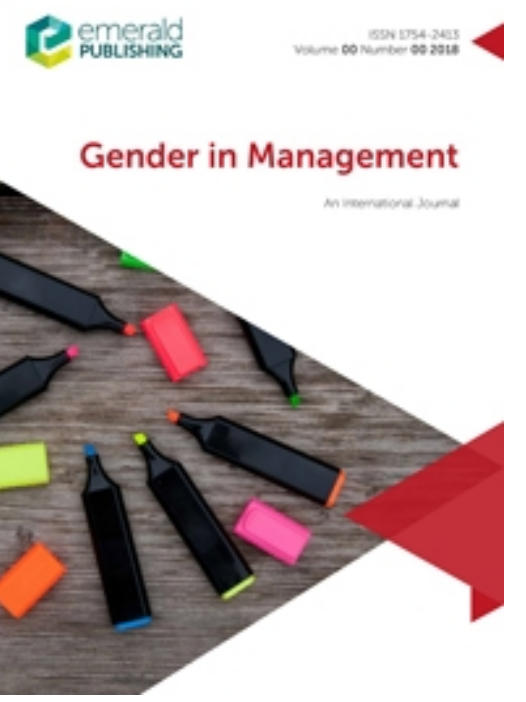

\title{
Busy Female Directors: An exploratory analysis of the impact of quotas and interest groups
}

\begin{tabular}{|r|l|}
\hline Journal: & Gender in Management: an International Journal \\
\hline Manuscript ID & GM-07-2019-0129.R4 \\
\hline Manuscript Type: & Original Article \\
\hline Keywords: & $\begin{array}{l}\text { Busy Directors, Overboarded Directors, Gender Diversity, Interlocking } \\
\text { Directorates }\end{array}$ \\
\hline
\end{tabular}

\section{SCHOLARONE ${ }^{\mathrm{m}}$ \\ Manuscripts}


TITLE: Busy Female Directors: An exploratory analysis of the impact of quotas and interest groups

\begin{abstract}
Purpose This paper provides an exploratory analysis of male and female directors, comparing the case of UK FTSE 350 boards of directors for 2010 to 2018, with Norwegian boards from 2002 to 2018, to examine patterns of busy female directors. This paper considers the differences between the effects of interest groups' actions and those of quotas on the emergence of busy female directors.
\end{abstract}

Design/methodology/approach This paper uses a longitudinal approach, providing an examination of both non-busy directors and busy directors sitting on the boards of UK and Norwegian firms, with a focus on female directors. Drawing on methods from Social Network Analysis, several trends and patterns are mapped for the two corporate systems. The paper tests whether the proportion of busy male directors is significantly different from the proportion of busy female directors in the two institutional settings.

Finding The results show there has been an increase in the proportion of busy female directors, whilst the level of busy male directors is slightly decreasing in the UK from 2010 to 2018. In Norway, following the introduction of gender quotas on corporate boards, there has been an increase in overboarded directors, especially female directors, along with the rise of so-called "golden skirt" directors. However, when compared to the UK case, the proportion of busy male and female directors is higher, suggesting that the emergence of the golden skirts in Norway is not a result of quotas alone. 
Originality/value The topic of busy directors has received increased attention in recent years, yet the gender of these directors is often neglected. This paper provides an overview of the characteristics of busy female directors for large UK and Norwegian firms, presenting avenues for future research.

\section{Keywords}

Overboarded directors; busy directors; gender diversity; interlocking directorates

\section{INTRODUCTION}

This paper provides a comparative analysis of the directors sitting on the boards of UK FTSE350 companies from 2010 to 2018 and directors sitting on large Norwegian public corporations from 2002 to 2011. This work reviews the characteristics of busy directors, with a focus on the differences between male and female busy directors. "Overboarded" directors are those with multiple appointments to boards of directors; they are also referred to as "busy" directors (Fich and Shivdasani, 2006). The study examines changes in the number of overboarded female directors as a result of interest group action in the UK and the implementation of quotas in Norway, and it investigates the characteristics of these directors.

The topic of busy directors has been an area of debate in recent years and has received attention from academics and policymakers alike (Ferris, Jayaraman et al., 2018; Garner et al., 2017). The issue has been highlighted as particularly important for female directors. This has been a particular topic of interest in the UK, where the Financial Reporting Council (FRC) is proposing new regulations regarding busy directors, with the goal of encouraging them to resign one or more of their positions. The FRC notes that there should be careful consideration when deciding to appoint a director with many existing directorships, and that the justification for appointing 
these busy directors should be included in the company's annual report (FRC, 2018). Furthermore, the Institutional Shareholder Services (ISS) (an influential body providing guidance on how institutional investors should vote at annual meetings where directors are elected) recommends that votes should be withheld for directors with more than six appointments (Institutional Shareholder Services, 2017). Governance codes, as opposed to legislative action, are frequently used to tackle the issue of director busyness (Moursli, 2020). Director "busyness" is a particular issue for female directors: increased legislative and interest group pressure has resulted in many firms increasing the levels of female representation on their board of directors, often sourcing from a pool of women that already hold directorships, thus contributing to the issue of director busyness.

For the UK, 2010 has been selected as the base year for this study as it represents an important milestone for gender diversity on boards of directors. Following several high-profile reviews highlighting the underrepresentation of women on UK boards (including the Cadbury Report (1992), the Higgs Review (2003) and the Tyson Report (2003)), 2010 saw the establishment of a prominent interest group, the $30 \%$ Club. This is a self-organised interest group set up to campaign for an increase in female representation on the boards of directors of the top $100 \mathrm{UK}$ public companies to at least $30 \%$ by 2015 . In 2015 , with this target in sight, the club announced two new key campaign goals: firstly, 30\% female representation on FTSE 350 boards by 2020; and secondly $30 \%$ female representation in senior management within FTSE 100 companies by 2020. This is aligned with recommendations set out in the Davies Review in 2015 calling for a minimum of $33 \%$ female representation on the corporate boards of the FTSE350. There is evidence of progress being made towards achieving these goals; Vinnicombe et al. (2015) discuss 
the board diversity patterns of the FTSE 100 in 2015, noting that all-male boards have disappeared amongst these firms.

Despite the efforts of such interest groups and initiatives, many argue that self-regulation on board gender diversity alone is not effective to increase the proportion of female directors, unless there is a threat from regulators of legislative action (Mensi-Klarbach et al., 2019). In this paper, we compare the UK with the case of Norway: this allows us to examine the impact of interest group activity against an institutional setting where quotas have been introduced. In 2003, Norway introduced quotas to ensure that $40 \%$ of directors on the boards of publicly listed firms are the underrepresented sex; this quota took full effect in 2008 (Strøm, 2015). Non-compliance with the quota can result in multiple sanctions ranging from fines until compliance to dissolving the company. We examine the case of Norway from 2002 to 2011, as this time period captures the announcement and implementation of the quota. The implications of introducing quotas on gender equality in the corporate system have been an area of interest for many years: the Norwegian setting has often been analysed for information on the dynamics between the two (Seierstad and Huse, 2017). The implementation of gender quotas for corporate boards in Norway has triggered a snowball effect and has been seen as an example to follow throughout Europe, where subsequent quotas have been implemented in Spain, Italy and France (Rebérioux and Roudaut, 2019).

Seierstad and Opsahl (2011) identified that a consequence of the quota in Norway was the rise of a small group of women holding many directorships; these women have been referred to as "golden skirts". This perspective assumes that, within an institutional environment with a quota regime, the social capital of female directors tends to be elitist, rather than a tool for supporting gender diversity in the corporate system (Rigolini and Huse, 2019). 
This study will compare the institutional context of the UK with Norway, contrasting the patterns of female directors in the UK where there is interest-group activity to promote female representation on corporate boards, along with a "comply or explain" principle, with the quotas approach observed in Norway.

The data is analysed through the lens of network analysis, where the relationships between firms and directors are considered as a network. This is an established approach to analyse director patterns and the impact on firm-level outcomes (Heemskerk et al., 2018). This type of network is referred to as an interlocking directorate network, when an individual sits on the boards of directors for multiple firms, providing a link (or interlock) between these firms. When examining patterns of director appointments, a network perspective acknowledges that individuals and firms are not independent, rather they are embedded in a system of personal connections and business relations (Uzzi, 1996). A network approach also complements other descriptive measures and allows an examination of the corporate system as a whole.

\section{LITERATURE REVIEW}

The literature of interlocking directorates is extensive, addressing a wide range of topics, as demonstrated by the seminal review of Mizruchi (1996). Interlocking directorates have been examined to investigate the corporate governance patterns of firms. Davis (1996) argues that empirical work often links interlocks to almost all important elements of corporate governance, ranging from executive compensation to a firm's takeover strategy.

Resource dependency theory is often applied to understand interlocking directorates and, more specifically, why they are formed. This framework suggests these network ties act as a mechanism for firms to access essential sources of advice and information (Pfeffer and Salancik, 1978), which can be used to mitigate environmental uncertainties. This theoretical framework is 
also used to explore the appointment of female directors, focusing on the resources and critical benefits that female directors can bring to a firm (Gabaldon et al., 2016). Resource dependency theory suggests that linkages to other firms can provide benefits to firms in terms of advice, legitimacy, and resources. The appointment of female directors adds legitimacy to a firm, reflecting public sentiment and policy recommendations calling for an increase in the number of women on boards (Hillman et al., 2002). A resource dependency perspective would not consider the issue of busy or overboarded directors to be a disadvantage, rather it would suggest that these multiple directorships provide the firm with higher levels of resources and information. There have been various studies utilising a resource dependency perspective on the impact of director interlocks on firm performance; however, there is a lack of consensus on whether they have a positive or negative impact (Santos et al., 2012; Zona et al., 2018).

In addition to resource dependency theory, there is a variety of theoretical frameworks to explain corporate boards, and the impact of female directors. These include agency theory (Jensen and Meckling, 1979) and institutional theory (Meyer and Rowan, 1977). Agency theory argues that female directors are better at monitoring activities, as they are often more independent than male directors since they are typically not part of the "old boys' network" (Kirsch, 2018). Institutional theory is concerned with how country rules, processes and norms guide corporate behaviour (Caiazza et al., 2019). Firms are embedded in an institutional environment, where their corporate behaviour and structures are a result of these institutional contexts and regulation. This theoretical framework has been utilised to understand why some countries impose quotas on the corporate system and why others do not (Terjesen et al., 2015).

The area of gender diversity and interlocking directorates has received increased attention in recent years (Singh et al., 2008), addressing several research topics. Amongst them is the topic of 
corporate governance and, more specifically, how gender diversity in the upper echelon of management impacts firm-level corporate governance practices. The monitoring role of directors plays an integral part in the corporate governance of a firm. The gender composition of the board can improve the quality of monitoring activities and therefore improve the overall value of the firm (Campbell and Mínguez-Vera, 2008).

The impact of increased board gender diversity on firm performance has also received increased attention in recent years. Many studies find that gender diversity has a positive impact on firm performance (Ali and Shabir, 2017; Moreno-Gómez et al., 2018). In particular, these studies find that firms with diverse boards exhibit lower risk and perform better (Perryman et al., 2016).

However, there are also several studies that find no impact (or even a negative impact) of gender diversity on firm performance. One argument proposed against diversity is that it leads to a greater variety of opinions and critical debate, which may result in board decisions and meetings becoming increasingly time-consuming, resulting in a less effective board compared with a homogeneous board of directors. However, this argument is only valid for firms operating in competitive environments where reacting quickly to shocks and events is essential (Smith et al., 2006). In their examination of UK firms, Gregory-Smith et al. (2014) find no effect of gender diversity on firm performance, and suggest that the motivation for achieving gender diversity on a board should not be value-driven, but should be motivated by moral and ethical values.

Within the literature on corporate governance, firm performance and interlocking directors, there is a substantial body of empirical work considering other research areas, including the notion of busy directors. Whether busy directors are a valuable resource or a burden on a company is a matter of debate (Ferris, Liao, et al., 2018). Some argue that the fact that some directors hold multiple appointments reflects their abilities. Others argue that directors with several 
appointments are ineffective because they have too many commitments. In their analysis of US firms, Fich and Shivdasani (2006) find that boards with multiple busy directors are associated with weak corporate governance, where busy directors are not effective monitors. Therefore, busy boards (boards with multiple overboarded directors) have a negative impact on firm performance. Subsequent empirical work investigating the link between director busyness and firm performance has found a similar negative impact (Fernández Méndez et al., 2015), especially in the case of US firms (Liu and Paul, 2015).

However, Field et al. (2013) show that, although busy directors are often not effective monitors, their extensive contacts make them excellent advisors on the board; this results in a positive effect on firm performance. Harris and Shimizu (2004) find that overboarded directors do not have a negative impact on firm outcomes, rather busy directors are complementary to the board.. Ferris, Jayaraman et al. (2018) find a negative association between busy boards and firm value, but also that the reverse is true for younger firms. This indicates that younger firms benefit from the wider network of busy directors, while more mature firms require a different corporate governance structure with greater monitoring, where a busy director could be less effective.

The role of gender in the busy directors' research is often neglected, with only a selection of empirical work considering the differences between female and male directors. The literature addressing the role of gender and director busyness has its roots in the case of Norway and the introduction of quotas regarding the representation of women on boards (Huse and Seierstad, 2013; Seierstad and Huse, 2017). As noted before, the outcome of the introduction of a quota was a marked increase in the representation of female directors on Norwegian boards by a small group of elite women sitting on multiple boards of directors (Seierstad, 2010). These women 
have been referred to as "golden skirts" and could be viewed as overboarded female directors (Seierstad and Opsahl, 2011).

The implementation of quotas to encourage gender diversity has been a salient topic, often featuring prominently on the political agenda. The extant literature on the use of quotas to promote gender diversity in corporate settings has often been concerned with whether the implementation of a quota has a positive impact on a firm-level outcome, frequently drawing on the Norwegian case (Reddy and Jadhav, 2019). The impact of quotas on firm performance is contested, with a lack of consensus on the issue: empirical studies identify both positive (Nygaard, 2011) and negative (Bøhren and Strøm, 2010) impacts. Ahern and Dittmar (2012) provide an examination of Norwegian firms and find that the implementation of quotas has resulted in many corporate boards becoming less experienced. However, Dale-Olsen et al. (2013) argue that the impact on firm performance of gender-related quotas is negligible. These arguments focus on the business case for gender diversity (and therefore the use of quotas). Other motivations for the implementation of legislation include justice and ethical motivations: that the benefits of quotas are to society rather than firms (Ferreira, 2015). This is especially reflected in the Norwegian case, where the ethical consideration was a larger motivator than the business case.

Regardless of the downsides, quotas remain an effective tool in encouraging sharp increases in the representation of female directors on corporate boards, with the benefits often outweighing the negative implications (Morgenroth and Ryan, 2018).

Legislative approaches to tackle gender diversity in the corporate setting range from hard, binding laws through soft, non-binding laws, to a voluntary approach. Norway is an example of a hard law, where there are harsh sanctions for non-compliance. The Spanish case is an example of 
a soft-law approach, where there are limited, or no, sanctions for non-compliance.. de Cabo et al. (2019) argue that this soft-law approach reflects a lack of commitment to quota regimes and therefore does not fully trigger the adoption of gender equality in the boardroom. Similarly, Piscopo and Clark Muntean (2018) note that soft-law approaches only lead to increases in the short term. The voluntary (or self-regulation) approach is a further option, where firms are encouraged, often through governance codes with a "comply or explain" element, to promote gender diversity in the boardroom. There is substantial debate about whether self-regulation can be truly effective, as governance codes are often argued to be insufficient without any other legislative action (Mensi-Klarbach et al., 2019).

Whether hard or soft legislative measures are implemented to encourage gender equality differs depending on the institutional settings (Carrasco et al., 2015). Terjesen et al. (2015) note that there are three institutional factors that increase the likelihood of the adoption of gender quotas: female labour market and gendered welfare provisions; left-leaning political governments; and path-dependent policy initiatives for gender quality. Therefore, it is no surprise that Norway, which meets these criteria and has a historical ideology for gender equality, has implemented quotas with high levels of support. In the UK, although there are several campaign groups, the legislative approach is non-binding, and is centred on a "comply or explain" approach. This is unsurprising, given there is little appetite in the UK for interventionist solutions to the gender diversity issues, with strong anti-regulatory sentiments observed (Doldor, 2017) . In the UK, the case for gender diversity is built around the business case, in contrast to Norway, which focuses on ethical considerations.

This paper aims to address the gap in the literature, the intersection between gender and director busyness, along with examining how this differs depending on whether hard or soft legislative 
action is adopted. Much of the literature focuses on director busyness, without accounting for gender and, more importantly, gender equality legislation. Therefore, in this paper, the following research questions are addressed.

RQ1: How have the proportions of busy directors, in particular busy female directors, changed in an institutional setting characterised by a quota regime compared to one with no formal legislation? How has the structure of the corporate system changed following key dates for gender equality?

RQ2: Is the proportion of male busy directors significantly different from that of female directors in these two institutional settings following key dates for gender equality activity? Are "golden skirts" observed in both the UK and Norway?

\section{DATA AND METHODS}

\section{Data}

The firms in this study are from two different institutional contexts: the UK and Norway. In the UK case, members of the FTSE 350 are examined. Constituents of the FTSE 350 represent large and mid-sized firms listed on the London stock exchange (the top 350 firms listed on the stock exchange).

The study covers the directors of these firms from 2010 to 2018. Data on directors is extracted from a combination of Companies House (British government website) and Bureau van Dijk's Orbis.

In our examination of Norwegian firms, we utilised the dataset developed by Seierstad and Opsahl (2011). This dataset provides information on Norwegian firms from 2002 to 2011, more specifically, the 384 public limited companies in Norway. These are companies that are bound by 
the quota legislation. Whilst 2010 represents a milestone for the UK, regarding interest group action, 2003 is a milestone year for Norway as this was when the quota was announced in the country.

In this analysis, busy directors are defined as those with three or more appointments in the interlocking directorates system. This definition follows those observed in the literature (Elyasiani and Zhang, 2015).

\section{Methods}

In this study, we compare patterns and characteristics of corporate directors, in particular female directors (both busy and non-busy) for the UK and Norway. We also examine the features of the corporate systems for the two institutional settings, drawing on methods from Social Network Analysis (SNA). SNA is frequently utilised as a methodological tool to understand patterns and trends within various corporate systems. We make use of a variety of concepts from SNA to explain and compare features of the corporate system in the UK and in Norway. These concepts include network density, fragmentation, and transitivity. Network density is a measure of network connectivity. It is the proportion of observed ties to the total possible number of ties (Borgatti et al., 2018). Fragmentation is the proportion of actors (nodes) that cannot reach each other through network ties, either directly or indirectly. Transitivity in the case of interlocking directorates is the proportion of connected quadruples (two directors sit on the boards of the same two firms) to open quadruples (where one of the directors only sits on the board of one of the firms) (Borgatti, 2012). We also draw on SNA to capture the busyness of directors, utilising the concept of degree centrality. Degree centrality counts the number of ties an actor has in a 
network, (Freeman, 1978). In the interlocking networks, degree centrality of individuals refers to the number of firms where individuals hold directorships.

We also complement this with a descriptive analysis of the data, examining proportions of male and female directors along with the proportions of male and female busy directors over the time period. Additionally, we make use of a Chi-Squared test to examine the differences between the proportions of directors (male and female) classified as busy.

\section{RESULTS}

\section{Characteristics of the corporate systems}

Table (1) presents several characteristics of the network, such as density, fragmentation and transitivity, along with the proportion of firms and directors in the main connected component of the network; the results are presented for only three time points for easier readability. The results highlight a key difference between the UK and Norwegian interlock networks. For the UK, the main connected components of these networks have become increasingly smaller over time, containing a smaller proportion of both directors and firms. In Norway, however, after the introduction of quotas the main component became larger, including a greater proportion of firms and directors. This may have been a result of the rise of the "golden skirts", where these women played a role in connecting a greater number of firms to the main component.

The density results indicate that the connectivity of these networks has remained low and decreased over the time period (although the magnitude of the decrease is not substantial) for both the UK and Norway. The fragmentation results indicate that, in the case of the UK, this has decreased steadily since 2010 (although not substantially), showing that the interlock network is 
becoming increasingly less fragmented. Similar patterns can be observed in Norway from 2002 to 2011, with fragmentation decreasing, yet with the levels slightly lower than the UK case. This again, might point towards the golden skirt directors playing a role in connecting the corporate system in Norway. Like density, transitivity has remained stable for both the UK and Norway, where there appears not to have been a significant increase in the clustering of interlock ties.

Insert Table 1 about here.

\section{Board Characteristics}

Table (2) shows the average board size of firms for the UK and Norway, the proportion of female directors and the proportion of "diverse" boards. The average board size results indicate that the size of FTSE 350 boards has grown steadily, whilst for Norway the average has remained consistent (between 6 and 7 directors) and the average board size did not increase following the implementation of the quota. To avoid the sanction associated with non-compliance, this suggests that, on average, corporate boards in Norway must have 2 or 3 female directors. There have been debates regarding the ideal board size: in Spain, a number of recommendations outlined by the Olivencia code suggest the ideal board size is between 5 and 15 individuals, although this recommendation was never adopted (Campbell and Mínguez-Vera, 2008). It is observed that, for the FTSE 350 firms, the average board size is in line with these recommendations, moving towards the upper limit by 2018, and from 2002 to 2011, these listed Norwegian firms are consistently within the limit.

Insert Table 2 about here. 
In the UK, the proportion of female directors has also increased, with a higher proportion of female directors serving on the FTSE 350 firms in 2018 compared to 2010. However, the proportion of female directors is still relatively low and not close to equal representation. In the case of Norway, since the implementation of quotas, there has clearly been an increase in the number of female directors, where the increase appears to occur much quicker and more substantially than in the UK. However, this level does reflect the quota requirement to have $40 \%$ representation of the underrepresented sex, potentially highlighting an issue emerging from the rise of the "golden skirts".

Kramer et al. (2006) assert that at least three women are required on a board of directors to change the group dynamic and benefit from increased female representation; this definition has also been utilised in other studies (Torchia et al., 2011). Following this approach, boards with at least three female members are considered diverse boards. Table (2) presents the number of firms with a diverse board of directors. Although the proportion of female directors remains low in the UK, the number of diverse boards has increased substantially since 2010, with over four times more diverse boards in 2018. For Norway, the use of this definition contrasts to the one proposed by the quota - the $40 \%$ level. The results indicate that the proportion of diverse boards (boards with three female directors) is greater in the UK following interest group action, than in Norway, where there is a quota regime. This is potentially a result of the smaller board sizes of Norwegian firms, where having fewer than 3 female directors is still in line with the quota. However, this potentially explains why the impact of quotas on firm outcomes is negligible: there is not a sufficient number of female directors (according to Kramer et al., 2006) for increased representation to significantly change the dynamics and to produce an impact on firm outcomes. 


\section{Busy directors}

The results have provided an overview of diversity on the boards of companies in the UK and Norway. However, the main objective of this study is to investigate busyness and, more specifically, busyness among female directors. To achieve this, interlocking directorate networks for the UK and Norway are analysed.

Figure (1) maps the average number of directorships for men and women for the UK and Norway, indicating several interesting trends. Overall, in the UK, for both men and women, there has been a decline in the average number of directorships, with a steep decline for male directors between 2010 and 2015. A similar trend can be observed for female directors. However, in 2014, the average number of appointments for female directors overtakes average appointments for male directors. This suggests that, although there are more men sitting on the boards of the FTSE 350 , on average it is women who hold more appointments.

For the Norwegian case, there was a decline in the average number of directorships from 2002 to 2007; following this, however, there was a rise in the average number of appointments, with a consistent trend for both male and female directors. Even though there was a rise in the average number of directorships, it did not reach the levels observed in 2002. When comparing the two cases, there has been no increase in the average number of directorships in the UK, yet, in Norway, there have been increases since the full implementation of the quotas. This points towards an increase in directors with multiple appointments (who are busier); this indicates that the issue of busy directors appears to be more prominent in Norway following full quota implementation than in the UK following interest group pressures. 
Insert Figure 1 about here.

The analysis of the dataset so far has provided some information on the characteristics of male and female directors, and the differences between them for the UK and Norwegian cases. Overall, in the UK, the proportion of directors that are female has been on the rise, yet still remains low. But the representation of women has increased, that is the number of diverse boards has increased. In Norway, from 2002 to 2011, there has clearly been an increase in the representation of women on corporate boards following the introduction of the quota, however, these levels are not at the same level as the $40 \%$ quota. This points towards the issue of "golden skirts" in Norway, indicating there is a set of elite women occupying key positions in the corporate system and suggesting that the quota has not fully addressed the gender inequality and discrimination observed in boards.

The second research question presented in this paper asks whether the proportion of male directors classified as busy is significantly different from the proportion of female directors classified as busy in the two institutional contexts. Table (3) presents the results from a statistical analysis (following a similar approach utilised by Marsland and Hawarden, 2011) to examine whether the proportions of female and male busy directors are significantly different in 2010 , 2014 and 2018 for the UK case, and 2002, 2006 and 2010 for the Norwegian case. There is a significant difference between the proportion of busy male directors and the proportion of busy female directors in latter stages of the two time periods for the UK and Norway. Yet the result is amplified in the case of Norway, where the difference between busy female and male directors is significant at the 0.01 level, compared to the 0.05 for the UK case. 
Insert Table 3 about here.

Figure (2) indicates the maximum number of appointments a male or female director has for the UK and Norway over the two respective time periods. This shows the number of appointments of the busiest directors during the time period. The number of appointments of the busiest male directors in the UK has decreased since 2010, whilst there has been an increase in appointments for the busiest women. This suggests that busyness is an important aspect of the appointment of female directors, where the busiest female directors are increasingly busy. In Norway, the maximum number of appointments is substantially greater than in the UK. For female directors, this begins to increase in 2005 (before the full implementation of the quota) and peaks in 2007 at 10 appointments. For male directors, this is also high, with the maximum going over 10 appointments in 2008, indicating that director busyness and the problem of a set of elite directors is not unique to female directors in Norway. For male directors, however, after 2009 the number dips below that observed for female directors.

Insert Figure 2 about here.

Figure (3) presents the proportion of total male and female directors respectively who are busy, the proportion of total male directors who are classified as busy and the total proportion of female directors classified as busy. It is observed that for both the UK and Norway, the proportion of women classified as busy has overtaken the proportion of male directors classified as busy. In the UK, for both male and female directors, only a very small proportion for each gender are classified as busy. For male directors, this proportion appears higher in 2010, and has experienced little change over time. In contrast, it is observed that the proportion of female busy 
directors has steadily increased since 2013, especially in more recent years. However, the proportion still remains low; this low proportion of female directors classified as busy suggests that there is no clear elite set of women in the data, as the majority have single appointments. This suggests that in FTSE 350 companies during the time period, the emergence of "golden skirts" is not observed.

This contrasts with the case of Norway, where the proportion of directors classified as busy is much larger than in the UK for both male and female directors, again highlighting a wider problem of director busyness in Norway. The overall trend is similar for female and male directors, with increases (with the exception of a dip in 2005 for female directors) and a peak in 2008; yet there is a much greater proportion of female directors classified as busy compared to their male counterparts. This provides support for the presence of "golden skirts" in the Norwegian corporate system. However, it is important to note that the proportion of directors classified as busy was higher for female directors than male directors prior to the announcement of the proposed quota regime. This suggests that, even prior to the implementation of quotas, busyness was an issue for female directors and that the quota system in Norway amplified this, leading to the formation of the group of "golden skirts".

A further point to note when discussing the issue of director busyness in Norway, is that the boards tend to be smaller than in the UK (as indicated by Table (2)). This has the potential to amplify the disadvantages of director busyness, where a larger proportion of the board may be unable to properly undertake monitoring activities.

Insert Figure 3 about here. 
The most prominent (yet not unexpected) difference between the Norwegian and UK cases is that the proportion of female directors was much higher in Norway than the UK and the changes occurred much faster. Further differences between the two cases are summarised in Table (4); there are patterns that suggest that director busyness is more visible in Norway than in the UK. The patterns are more prominent for female directors, pointing towards evidence of busy female director (or "golden skirts"), yet busyness also appears to be an issue for male directors, indicating that this is not an issue created by quotas alone.

Insert Table 4 about here.

\section{CONCLUDING COMMENTS}

This research provides a comparative analysis of the characteristics of directors in UK FTSE 350 companies between 2010 and 2018 and in Norwegian firms between 2002 and 2011. The study provides an examination of the gender differences of these directors, with a focus on how busy male directors differ from busy female directors.

This research poses two research questions. The first asks whether the proportion of busy directors has changed over the time periods for the UK and Norway. The analysis presented in this paper indicates that, in the UK, an increasing proportion of these female directors are classified as busy. However, the proportion of busy female directors in the UK does not reach the levels observed in Norway from 2002 to 2011. This suggests that director busyness is a more prominent issue in Norway than the UK, yet the introduction of a quota regime has increased the proportion of busy female directors, giving rise to the "golden skirts" (addressing the second research question posed by this paper) (Seierstad and Opsahl, 2011). 
The second research question addresses the issue of golden skirts directly, asking whether the proportion of busy male directors is significantly different from the proportion of female directors in these settings and whether we observe the phenomenon referred to as golden skirts. The results from the statistical analysis highlight the significant differences emerging between the proportions of male and female directors in more recent years. Furthermore, the results indicate that the issue of busy female directors (or "golden skirts") is evident in the Norwegian case, as demonstrated by Seierstad and Opsahl (2011), where the maximum number of directorships is substantial for female directors in Norway, especially when compared to the UK case. The analysis suggests that there is limited evidence of golden skirts in the UK. Although there is an increase in busy women, the proportion of women who are overboarded remains low.

An important point to acknowledge when comparing the cases of Norway and the UK is the role of legislators. In Norway, quotas regarding gender diversity have been implemented, whereas in the UK a voluntary option was presented (Doldor et al., 2012). Furthermore, there are notable differences between the actors driving the increase in the number of female directors on boards in the UK and Norway. Seierstad et al. (2017) find that, in Norway, state regulators and civil society are driving the increase in the number of women on boards. Whereas in the UK, it is primarily interest groups (they highlight the 30\% Club) and researchers that play important roles in driving the increase in numbers of female directors. In the UK, there is very little appetite for state intervention and regulation, where even amongst diversity campaigners there are few who vocally support the implementation of quotas. The contrast in legislation and the differences between the actors driving the increase in the proportion of female directors, explain the differences between gender and director busyness. 
The analysis indicates that, since 2010 in the UK there has been an increase in female representation in the corporate system. The growth of female representation in Norway, following the implementation of the quota, has been much faster, reaching higher levels when compared to the UK. This does highlight the advantages of formal legislation in promoting gender diversity over a shorter time period. However, given the resistance to regulatory intervention in the UK, it is unlikely that quotas would be as successful as in Norway. As noted by Seierstad (2016), quotas are more likely to be successful if they are supported by business and wider society. However, the quota in Norway is not without some limitations; for instance, even several years after the announcement of quotas in Norway, female representation in the entire corporate system did not reflect the $40 \%$ levels required.

The rise of the so-called "golden skirts" is a frequently cited weakness of gender diversity quotas. Therefore, there is a subsequent question, to which our analysis contributes: are quotas responsible for the busy female director? The analysis in this paper suggests that quotas are not entirely responsible for director busyness in Norway (and perhaps not even for the rise of the socalled "golden skirts"). As compared to the UK, male directors are also busier in Norway. This suggests that director busyness is perhaps the central issue, not just the rise of busy female directors.

Although the term "golden skirts" is used in this paper, and other areas of the literature, there is perhaps a need to shift from this in subsequent discussion, as it has negative connotations, related to the "old boys' network". However, whilst the old boys' network is a result of upper-class cohesion, the rise of "golden skirts" is a result of the limits set out by legislation, rather than a set of individuals' exploitative behaviours. A further salient point is that director busyness is also more prominent in Norway, when comparing male director patterns in the two countries, 
therefore this suggests that the rise of busy female directors is a more complex issue and not simply a result of quota adoption alone.

This study highlights the importance of considering male and female directors separately when investigating busy director patterns, as they follow different appointment trajectories, which may have implications for corporate governance practices. The analysis shows that, whilst the number of busy male directors is gradually decreasing, the number of busy female directors is increasing. In Norway, it appears that, although female directors are increasingly busy, director busyness is not an issue unique to female directors, especially when compared to the UK case. This suggests that in Norway, there is a need for further governance codes regarding the number of appointments a director should have, to complement quotas. This is also important given that boards in Norway tend to be smaller, which could potentially amplify the impact of director busyness. One approach would be to use soft, non-binding legislation, rather than hard legislation, as a first step to mitigate the issue of director busyness, for both male and female directors. A further solution to tackle the intersection of director busyness and gender equality when formulating hard, binding legislative quotas, would be to not only focus on percentages and proportions, but also to include the characteristics of the directors sitting on the boards (including the number of appointments they currently hold, the overall busyness of the board) (Arioglu, 2020). This approach would be in line with the overall aim of quotas to promote gender equality and inclusion and would mitigate the risk resulting from any quota legislation of a small elite rising and limiting equality outcomes.

In the UK, the analysis provides evidence that the campaign goals and objectives of the $30 \%$ Club and other initiatives to increase the representation of women on boards, are being met, as there has been a clear rise in the level of female representation on boards of directors and an 
increase in diverse boards since 2010. This suggests that self-regulation in the UK has begun to promote a cultural shift towards further gender equality in corporate settings. However, female representation remains low, especially when compared with the Norwegian case, with a much slower pace of progress (Doldor, 2017). Quotas, or any hard legislation, are unlikely to be successful in the UK, yet there may be a need for soft regulation, beyond the "explain or comply" approach, to promote further representation.

The results gave further information on the interplay between the introduction of quotas and the number of diverse boards (defined as having three female directors). The analysis indicates that although the proportion of female directors is typically lower in the UK, the proportion of diverse boards is higher than Norway. This is due to the smaller board sizes observed in Norway where, to fulfil the quota, there is not necessarily a need to have more than two female directors. This indicates that the size of the board is an important factor when formulating governance codes or legislation on representation. These results highlight the need to acknowledge different measures of board diversity, and the impact of strategic goals regarding gender diversity, whether these are set out by interest groups or by policy directives or governance codes.

A question that arises from this analysis is whether the affirmative action in Norway should shape the political and strategic decisions of legislative bodies and interest groups in the UK? The results indicate that the implementation of quotas has resulted in a rapid increase in female representation, whereas interest group action and associated initiatives in the UK have resulted in increased female representation at a much slower pace. Whilst some scholars suggest that the quota has resulted in rapid increased levels of female representation, it has come at a cost: the rise of the "golden skirts", pointing to a limitation of the legislation's power as a tool for supporting gender diversity in the corporate system. However, our analysis indicates that director busyness 
is not limited only to female directors, but also affects male directors in Norway, indicating it is not only the result of the binding legislation. Therefore, when weighing the benefits, and potential lessons learnt from the Norwegian case, the rise of the busy director, or the so-called "golden skirts", should not be used as a justification to resist any form of legislative action (either hard or soft).

We acknowledge that there are several limitations to the work presented here; amongst them is that this work is chiefly descriptive. Future research comparing busy and female directors should move beyond an exploratory approach to discuss in further detail the impact of a quota regime against an institutional setting without legislation. A further limitation is the use of a rather simplistic measure of director busyness; more complex measures of busyness could be explored, acknowledging the different characteristics of the different boards the directors sit on, and perhaps the characteristics of the directors themselves.

These results suggest several avenues for future research. Firstly, a follow-up analysis could examine what determines the appointment of busy female directors; this could include interviewing the chairs of nomination committees. Secondly, how does the presence of busy women on boards shape company performance? Do companies with overboarded female directors still reap the benefits of gender diversity on their boards? Finally, a qualitative study, employing in-depth interviews with busy female directors could provide insights into effectiveness. 


\section{REFERENCES}

Ahern, K.R. and Dittmar, A.K. (2012), "The changing of the boards: The impact on firm valuation of mandated female board representation", The Quarterly Journal of Economics, Vol. 127 No. 1, pp. 137-197.

Ali, J. and Shabir, S. (2017), "Does gender make a difference in business performance?", Gender in Management: An International Journal, available at:https://doi.org/10.1108/GM-092016-0159.

Arioglu, E. (2020), "Female board members: the effect of director affiliation", Gender in Management: An International Journal, Emerald Publishing Limited.

Bøhren, Ø. and Strøm, R.Ø. (2010), “Governance and politics: Regulating independence and diversity in the board room", Journal of Business Finance \& Accounting, Wiley Online Library, Vol. 37 No. 9-10, pp. 1281-1308.

Borgatti, S.P. (2012), "Social Network Analysis, Two-Mode Concepts in”, in Meyers, R.A. (Ed.), Computational Complexity: Theory, Techniques, and Applications, Springer New York, New York, NY, pp. 2912-2924.

Borgatti, S.P., Everett, M.G. and Johnson, J.C. (2018), Analyzing Social Networks, Sage.

de Cabo, R.M., Terjesen, S., Escot, L. and Gimeno, R. (2019), “Do 'soft law’board gender quotas work? Evidence from a natural experiment”, European Management Journal, Elsevier, Vol. 37 No. 5, pp. 611-624.

Cadbury, A. (1992), Report of the Committee on the Financial Aspects of Corporate Governance, Vol. 1, Gee. 
Caiazza, R., Cannella Jr, A.A., Phan, P.H. and Simoni, M. (2019), “An institutional contingency perspective of interlocking directorates", International Journal of Management Reviews, Vol. 21 No. 3, pp. 277-293.

Campbell, K. and Mínguez-Vera, A. (2008), "Gender Diversity in the Boardroom and Firm Financial Performance", Journal of Business Ethics, Vol. 83 No. 3, pp. 435-451.

Carrasco, A., Francoeur, C., Labelle, R., Laffarga, J. and Ruiz-Barbadillo, E. (2015), “Appointing Women to Boards: Is There a Cultural Bias?", Journal of Business Ethics, Vol. 129 No. 2, pp. $429-444$.

Dale-Olsen, H., Schøne, P. and Verner, M. (2013), "Diversity among Norwegian boards of directors: Does a quota for women improve firm performance?", Feminist Economics, Vol. 19 No. 4, pp. 110-135.

Davis, G.F. (1996), “The significance of board interlocks for corporate governance”, Corporate Governance: An International Review, Vol. 4 No. 3, pp. 154-159.

Doldor, E. (2017), “UK: The merits and shortcomings of a voluntary approach”, Gender Diversity in the Boardroom, Springer, pp. 13-44.

Doldor, E., Vinnicombe, S., Gaughan, M. and Sealy, R. (2012), “Gender diversity on boards: The appointment process and the role of executive search firms", Equality and Human Rights Commission Research Report, Vol. 85.

Elyasiani, E. and Zhang, L. (2015), “Bank holding company performance, risk, and 'busy' board of directors", Journal of Banking \& Finance, Vol. 60, pp. 239-251.

Fernández Méndez, C., Pathan, S. and Arrondo García, R. (2015), "Monitoring capabilities of busy and overlap directors: Evidence from Australia", Pacific-Basin Finance Journal, Vol. 35, pp. 444-469. 
Ferreira, D. (2015), “Board diversity: Should we trust research to inform policy?”, Corporate Governance: An International Review, Vol. 23 No. 2, pp. 108-111.

Ferris, S.P., Jayaraman, N. and Liao, M.-Y.S. (2018), “Better directors or distracted directors? An international analysis of busy boards", Global Finance Journal.

Ferris, S.P., Liao, M.-Y. (Stella) and Tamm, C. (2018), “The compensation of busy directors: An international analysis", Research in International Business and Finance, Vol. 46, pp. $294-312$.

Fich, E.M. and Shivdasani, A. (2006), “Are busy boards effective monitors?”, The Journal of Finance, Vol. 61 No. 2, pp. 689-724.

Field, L., Lowry, M. and Mkrtchyan, A. (2013), “Are busy boards detrimental?”, Journal of Financial Economics, Vol. 109 No. 1, pp. 63-82.

FRC. (2018), “The UK Corporate Governance Code”, Financial Reporting Council, available at: https:/www.frc.org.uk/getattachment/88bd8c45-50ea-4841-95b0-d2f4f48069a2/2018UK-Corpoate-Governance-Code-FINAL.pdf.

Gabaldon, P., Anca, C. de, Cabo, R.M. de and Gimeno, R. (2016), "Searching for Women on Boards: An Analysis from the Supply and Demand Perspective", Corporate Governance: An International Review, Vol. 24 No. 3, pp. 371-385.

Garner, J., Kim, T. and Yong Kim, W. (2017), "Boards of directors: a literature review”, Managerial Finance, Vol. 43 No. 10, pp. 1189-1198.

Gregory-Smith, I., Main, B.G.M. and O’Reilly, C.A. (2014), “Appointments, Pay and Performance in UK Boardrooms by Gender", The Economic Journal, Vol. 124 No. 574, pp. F109-F128.

Harris, I.C. and Shimizu, K. (2004), “Too Busy To Serve? An Examination of the Influence of Overboarded Directors”, Journal of Management Studies, Vol. 41 No. 5, pp. 775-798. 
Heemskerk, E., Young, K., Takes, F.W., Cronin, B., Garcia-Bernardo, J., Henriksen, L.F., Winecoff, W.K., et al. (2018), “The promise and perils of using big data in the study of corporate networks: problems, diagnostics and fixes", GLOBAL NETWORKS-A JOURNAL OF TRANSNATIONAL AFFAIRS, Vol. 18 No. 1, pp. 3-32.

Higgs, D. (2003), "Review of the role and effectiveness of nonexecutive directors", available at: www.dti.gov.uk/cld/non_execs_review.

Hillman, A.J., Cannella, A.A. and Harris, I.C. (2002), "Women and Racial Minorities in the Boardroom: How Do Directors Differ?”, Journal of Management, Vol. 28 No. 6, pp. 747763.

Huse, M. and Seierstad, C. (2013), "Getting women on to corporate boards: Consequences of the Norwegian gender balance law", The European Financial Review, Vol. 12, pp. 37-39.

Institutional Shareholder Services (ISS). (2017), “United States summary proxy voting guidelines_-2017 benchmark policy recommendations.", available at: https://www.issgovernance.com/file/policy/2017- us-summary-voting-guidelines.pdf. Jensen, M.C. and Meckling, W.H. (1979), “Theory of the firm: Managerial behavior, agency costs, and ownership structure", Economics Social Institutions, Springer, pp. 163-231.

Kirsch, A. (2018), “The gender composition of corporate boards: A review and research agenda", The Leadership Quarterly, Vol. 29 No. 2, pp. 346-364.

Kramer, V.W., Konrad, A.M., Erkut, S. and Hooper, M.J. (2006), Critical Mass on Corporate Boards: Why Three or More Women Enhance Governance, Wellesley Centers for Women Wellesley, MA.

Liu, C. and Paul, D.L. (2015), “A New Perspective on Director Busyness”, Journal of Financial Research, Vol. 38 No. 2, pp. 193-218. 
Marsland, S. and Hawarden, R.J. (2011), "Locating women board members in gendered director networks", Gender in Management: An International Journal, Vol. 26 No. 8, pp. 532549.

Mensi-Klarbach, H., Leixnering, S. and Schiffinger, M. (2019), “The carrot or the stick: Selfregulation for gender-diverse boards via codes of good governance", Journal of Business Ethics, pp. 1-17.

Meyer, J.W. and Rowan, B. (1977), “Institutionalized organizations: Formal structure as myth and ceremony", American Journal of Sociology, Vol. 83 No. 2, pp. 340-363.

Mizruchi, M.S. (1996), “What Do Interlocks Do? An Analysis, Critique, and Assessment of Research on Interlocking Directorates”, Annual Review of Sociology, Vol. 22, pp. 271298.

Moreno-Gómez, J., Lafuente, E. and Vaillant, Y. (2018), “Gender diversity in the board, women's leadership and business performance", Gender in Management: An International Journal, available at:https://doi.org/10.1108/GM-05-2017-0058.

Morgenroth, T. and Ryan, M.K. (2018), "Quotas and affirmative action: Understanding groupbased outcomes and attitudes", Social and Personality Psychology Compass, Vol. 12 No. 3, p. e12374.

Moursli, R.M. (2020), “The effects of board independence on busy directors and firm value: Evidence from regulatory changes in Sweden", Corporate Governance: An International Review, Vol. 28 No. 1, pp. 23-46.

Nygaard, K. (2011), "Forced board changes: Evidence from Norway".

Perryman, A.A., Fernando, G.D. and Tripathy, A. (2016), "Do gender differences persist? An examination of gender diversity on firm performance, risk, and executive compensation", Journal of Business Research, Vol. 69 No. 2, pp. 579-586. 
Pfeffer, J. and Salancik, G.R. (1978), “The external control of organizations: A resource dependence approach", NY: Harper and Row Publishers.

Piscopo, J.M. and Clark Muntean, S. (2018), "Corporate quotas and symbolic politics in advanced democracies", Journal of Women, Politics \& Policy, Taylor \& Francis, Vol. 39 No. 3, pp. 285-309.

Rebérioux, A. and Roudaut, G. (2019), “The Role of Rookie Female Directors in a Post-Quota Period: Gender Inequalities within French Boards", Industrial Relations: A Journal of Economy and Society, Vol. 58 No. 3, pp. 423-483.

Reddy, S. and Jadhav, A.M. (2019), "Gender diversity in boardrooms - A literature review", edited by P, Y.P.Cogent Economics \& Finance, Cogent OA, Vol. 7 No. 1, p. 1644703.

Rigolini, A. and Huse, M. (2019), "Women and Multiple Board Memberships: Social Capital and Institutional Pressure”, Journal of Business Ethics, pp. 1-17.

Santos, R.L., Silveira, A. di M. da and Barros, L.A. (2012), "Board Interlocking in Brazil: Directors' Participation in Multiple Companies and Its Effect on Firm Value and Profitability", Latin American Business Review, Vol. 13 No. 1, pp. 1-28.

Seierstad, C. (2010), "The use of quotas in the most equal region", Equality, Inequalities and Diversity: Contemporary Challenges and Strategies, p. 171.

Seierstad, C. (2016), "Beyond the business case: The need for both utility and justice rationales for increasing the share of women on boards", Corporate Governance: An International Review, Wiley Online Library, Vol. 24 No. 4, pp. 390-405.

Seierstad, C. and Huse, M. (2017), “Gender Quotas on Corporate Boards in Norway: Ten Years Later and Lessons Learned”, in Seierstad, C., Gabaldon, P. and Mensi-Klarbach, H. (Eds.), Gender Diversity in the Boardroom: Volume 1: The Use of Different Quota Regulations, Springer International Publishing, Cham, pp. 11-45. 
Seierstad, C. and Opsahl, T. (2011), "For the few not the many? The effects of affirmative action on presence, prominence, and social capital of women directors in Norway", Scandinavian Journal of Management, Vol. 27 No. 1, pp. 44-54.

Seierstad, C., Warner-Søderholm, G., Torchia, M. and Huse, M. (2017), "Increasing the Number of Women on Boards: The Role of Actors and Processes", Journal of Business Ethics, Vol. 141 No. 2, pp. 289-315.

Singh, V., Terjesen, S. and Vinnicombe, S. (2008), "Newly appointed directors in the boardroom:: How do women and men differ?", European Management Journal, Vol. 26 No. 1 , pp. $48-58$.

Smith, N., Smith, V. and Verner, M. (2006), "Do women in top management affect firm performance? A panel study of 2,500 Danish firms", International Journal of Productivity and Performance Management, Vol. 55 No. 7, pp. 569-593.

Strøm, R.Ø. (2015), “Gender discrimination before mandated quotas? Evidence from Norway: 1989-2002”, Scandinavian Journal of Management, Vol. 31 No. 3, pp. 303-315.

Terjesen, S., Aguilera, R.V. and Lorenz, R. (2015), “Legislating a Woman's Seat on the Board: Institutional Factors Driving Gender Quotas for Boards of Directors”, Journal of Business Ethics, Vol. 128 No. 2, pp. 233-251.

Torchia, M., Calabrò, A. and Huse, M. (2011), "Women directors on corporate boards: From tokenism to critical mass", Journal of Business Ethics, Vol. 102 No. 2, pp. 299-317.

Tyson, L. (2003), “The Tyson report on the recruitment and development of nonexecutive directors", available at: www.london.edu/tysonreport.

Uzzi, B. (1996), “The Sources and Consequences of Embeddedness for the Economic Performance of Organizations: The Network Effect", American Sociological Review, Vol. 61 No. 4, p. 674. 
Vinnicombe, S., Doldor, E., Sealy, R., Pryce, P. and Turner, C. (2015), “The Female FTSE Board Report 2015".

Zona, F., Gomez-Mejia, L.R. and Withers, M.C. (2018), "Board Interlocks and Firm

Performance: Toward a Combined Agency-Resource Dependence Perspective”, Journal of Management, Vol. 44 No. 2, pp. 589-618.

i This data can be found at http://boardsandgender.com/ 
TABLE 1: Characteristics of the interlocking directorate networks for the UK and Norway

\begin{tabular}{l|ccccc}
\multicolumn{2}{c}{ UK } & \multicolumn{2}{c}{ Norway } \\
\hline & $\mathbf{2 0 1 0}$ & $\mathbf{2 0 1 4}$ & $\mathbf{2 0 1 8}$ & $\mathbf{2 0 0 2}$ & $\mathbf{2 0 0 6}$ \\
Density & 0.0038 & 0.0035 & 0.0031 & 0.0052 & 0.0037 \\
Transitivity & 0.8871 & 0.8874 & 0.9044 & 0.8427 & 0.741 \\
Fragmentation & 0.9107 & 0.7996 & 0.7507 & 0.8427 & 0.71 \\
Proportion of firms in main component & 0.2964 & 0.2704 & 0.2399 & 0.3578 & 0.535 \\
Proportion of directors in main component & 0.2859 & 0.2203 & 0.1567 & 0.3927 & 0.536
\end{tabular}


0.0034

0.7158

0.5721

0.6575

0.6524 
TABLE 2: Board characteristics for UK and Norway

\begin{tabular}{l|cccccc}
\multicolumn{3}{c}{ UK } & \multicolumn{3}{c}{ Norway } \\
\hline & $\mathbf{2 0 1 0}$ & $\mathbf{2 0 1 4}$ & $\mathbf{2 0 1 8}$ & $\mathbf{2 0 0 2}$ & $\mathbf{2 0 0 6}$ & $\mathbf{2 0 1 0}$ \\
Average Board Size & 7.5429 & 8.9022 & 11.0751 & 6.4679 & 6.5623 & 6.1105 \\
Proportion of Female Directors & 0.1333 & 0.2187 & 0.2669 & 0.0982 & 0.2427 & 0.3695 \\
Proportion of Diverse Boards & 0.0857 & 0.2899 & 0.5723 & 0.0642 & 0.2006 & 0.3867
\end{tabular}


TABLE 3: Statistical test of proportion of gendered busy directors for the UK and Norws

\begin{tabular}{l|ccc}
\hline & \multicolumn{3}{c}{ UK } \\
\hline Proportion of female directors classified as busy & $\mathbf{2 0 1 0}$ & $\mathbf{2 0 1 4}$ & $\mathbf{2 0 1 8}$ \\
Proportion of male directors classified as busy & 0.0038 & 0.0036 & 0.0157 \\
$\chi^{2}$ & 0.0065 & 0.0065 & 0.0065 \\
\hline & 0.007 & 0.239 & $5.725^{*}$
\end{tabular}

Note: ${ }^{* * *} \mathrm{p}<0.001,{ }^{* *} \mathrm{p}<0.01,{ }^{*} \mathrm{p}<0.05$ 
ay

\begin{tabular}{ccc}
\multicolumn{3}{c}{ Norway } \\
\hline $\mathbf{2 0 0 2}$ & $\mathbf{2 0 0 6}$ & $\mathbf{2 0 1 0}$ \\
0.0244 & 0.0579 & 0.0653 \\
0.0186 & 0.0371 & 0.0329 \\
0.01 & 3.0038 & $9.4124^{* *}$
\end{tabular}


TABLE 4: Summary of differences in corporate interlock

CHARACTERISTICS OF THE NETWORK SYSTEM

AVERAGE BOARD SIZE

AVERAGE NUMBER OF DIRECTORSHIPS

PROPORTION OF MALE DIRECTORS CLASSIFIED AS BUSY

PROPORTION OF FEMALE DIRECTORS

CLASSIFIED AS BUSY

MAXIMUM APPOINTMENTS OF BUSY FEMALE DIRECTORS

MAXIMUM APPOINTMENTS OF BUSY FEMALE DIRECTORS 
data between the UK and Norway NORWAY UK

Main connected size increased

Constant

Declines from 2004 -2007 then slight increase

Constant

Steady increase

Ranges from 4 to 11

Ranges from 4 to 10
Main connected component size decreased

Increased over time

Declined over the time period

Constant

Increase from 2014

Ranges from 3 to 5 , decreasing over the time period

Range from 3 to 5 
Figure 1: Average degree of directors for males and females for UK \& Norway
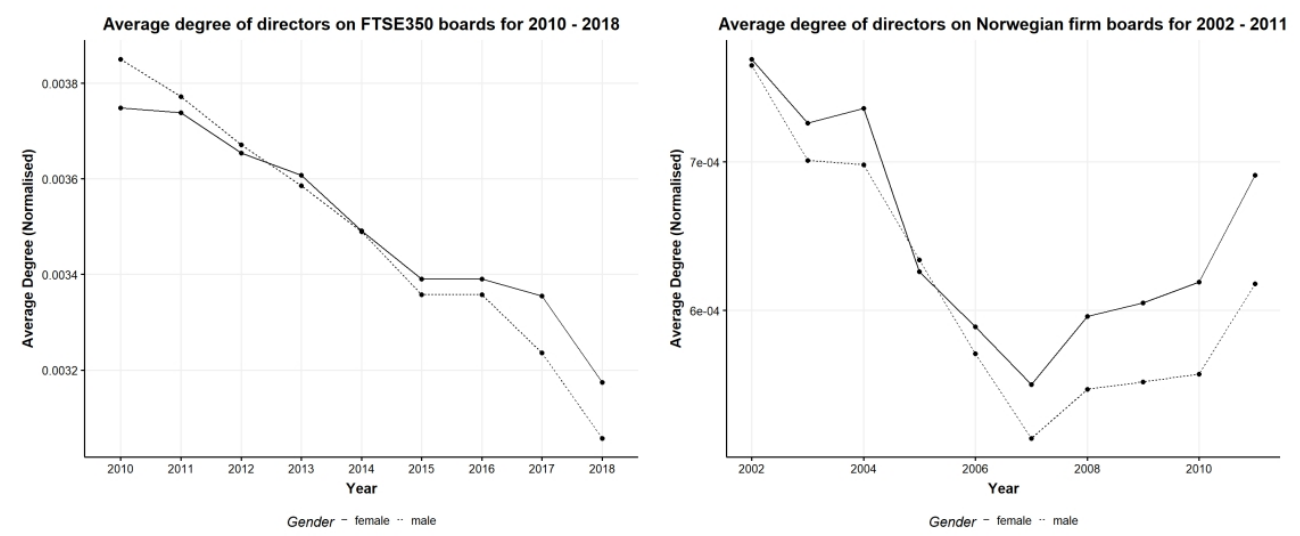

FIGURE 1: Average degree of directors for males and females for UK and Norway

$381 \times 177 \mathrm{~mm}(200 \times 200 \mathrm{DPI})$ 

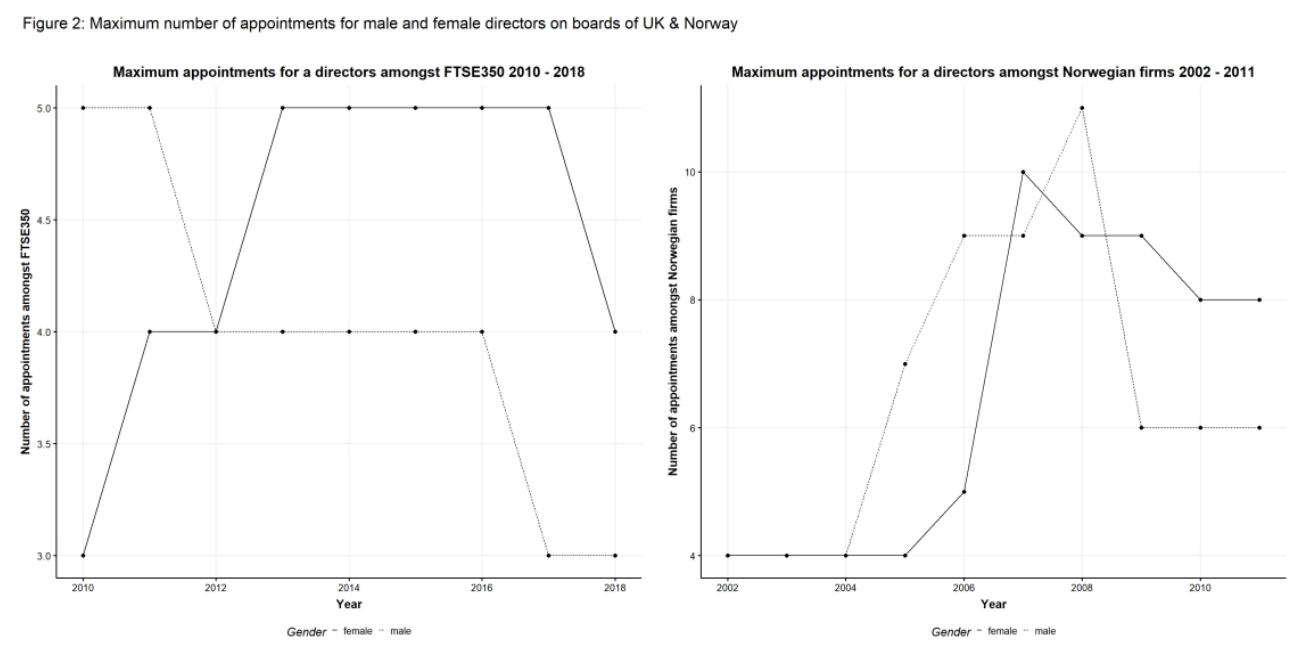

FIGURE 2: Maximum number of appointments for male and female directors on boards of UK and Norway $457 \times 228 \mathrm{~mm}(200 \times 200$ DPI $)$ 

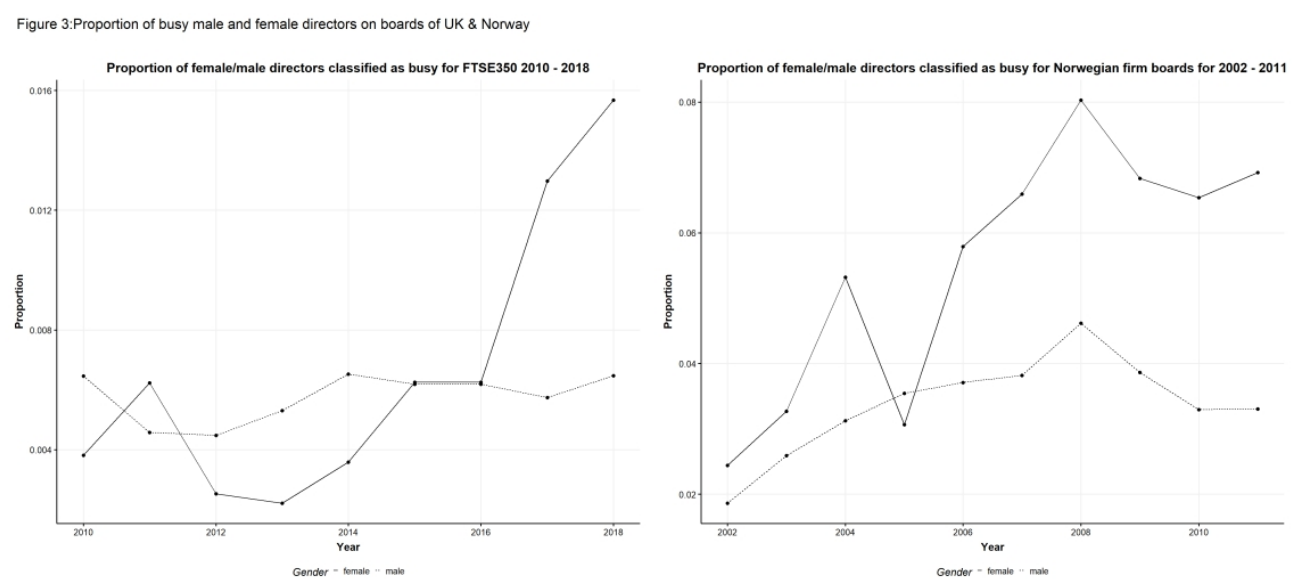

FIGURE 3: Proportion of busy male and female directors on boards of UK and Norway $508 \times 228 \mathrm{~mm}(200 \times 200$ DPI $)$ 